\title{
Mushroom Production: Cost Effective Use of Soyabean Meal (De- Oiled Cake) During Composting
}

\author{
Dr. Parveen Garg \\ Department of Botany, Swami Shradhanand College, University of Delhi, Alipur, Delhi- 110036
}

\begin{abstract}
Considering the constraints due to unavailability of uniform quality chicken manure in local market, three different combinations of wheat and soyabean meal (de-oiled cake) were tested for their ability to affect yield and cost of production of Button Mushroom (Agaricus bisporus). Compost was prepared by mixing 18, 22 and $25 \%$ soyabean meal with wheat straw by short method of composting. $80 \%$ chicken manure with wheat straw was the control. All the ingredients composted for 18 days of two phases composting using tunnel for peak heating as advocated by Shandilya et al, 1976, fresh grain spawn was obtained from Bharat Mushrooms, Delhi, India. Formaldehyde treated casing soil (2:1 mixture of 2 year old farm yard manure and garden soil) was used for casing of beds. The results indicate that all the combinations affected yield and proved to be promising factors for low cost production of mushroom. Combination with $22 \%$ soyabean meal gave the maximum production of Mushroom (226 Kg/ton of compost).
\end{abstract}

Subject: Basic science

Keywords: Soyabean meal, Agaricus bisporous, Compost

\section{Introduction}

Mushroom being Hetrotrophic organism obtains all nutritive elements form the substrate - the compost. Therefore compost plays a more comprehensive and important role in mushroom production that does soil in higher plants. Compost is the substrate on which mushroom grows. This material is the result of decomposition process governed by a number of micro - organisms that produce important chemical and biological reactions thereby making it selective for Agaricus bisporus.

Due to non availability of Horse manure compost, formulation based on wheat straw plus other nutrients (organic and inorganic) has become the standard formulation and is being adapted by all the commercial mushroom units of India. Various formulations have been developed by different workers from time to time mainly based on locally available materials (Schisler 1974; Shandilya 1976; 1980; Hayes and Shandilya 1977; Dhar et al. 1985), Chicken manure which is being used most efficiently and economically to supplement the wheat straw is losing its potency due to certain scientific, social and environmental barriers. Generally chicken manure is mixture of bird droppings, poultry feed and saw dust and never found to be homogenous in nature. Under uncovered yards it is exposed to severe climatic changes like rain, wind and temperature that makes it unfit to be used as uniform biological entity. Chicken manure lying outside in open fields soaks water in rainy seasons and breaks down its nitrogen vary rapidly. This causes a loss of its nutritional value. Wet chicken manure forms hard lumps that mix unevenly and become anaerobic lumps during phase I composting. This also cause odors in the yard and reduces compost quality. Even more demanding than compost quality has become the social issues of odor and air quality problems. Odor problems have already been paid attention and therefore promoted much research and various changes in compost production methods. Air quality problems during phase I composting have forced the growers to change the operations significantly (Miller 1993). Hence the objectives of our studies were to determine the effects of soyabean meal as a potent alternative to chicken manure. The present investigation deals with the addition of easily available cheap and nutritional organic source.

\section{Materials And Methods}

Wheat straw and chicken manure were procured locally. Soyabean meal (De-Oiled Cake) having protein content (42-46\% of dry wt.) was taken from Aarti Agro Industries, New Delhi. Fresh grain spawn of Agaricus bisporus (lange) sing, strain S11 was obtained form Bharat Mushrooms, Delhi, India, Formaldehyde treated casing soil (2:1 mixture of 2 year old farm yard manure and garden soil) was used for casing of beds.

Wheat straw based compost was prepared by short method. All the ingredients were composted for 18 days of two phases composting using tunnel for peak heating advocated by Shandilay et. Al. 1980. Pre - wetting takes place 2-3 days followed by 7 days of outdoor composting on concrete floor. 
Supplements like chicken manure of different concentrations or soyabean mean was sprinkled over it on first day of stacking. Gypsum was added on $7^{\text {th }}$ day. Initial nitrogen content of the compost pile was kept about $1.70-1.75 \%$.

Spawn was mixed with the compost of $0.6 \%$ by through spawning method in all the twenty four trays each containing $80 \mathrm{~kg}$ of compost ( $72 \%$ moisture). Spawned trays were covered with polythene sheets. After spawn run polythene sheet was removed and the trays were cased with formaldehyde (41\%) treated casing soil to a thickness of $4.0 \mathrm{~cm}$. Regular watering and appropriate ventilation specially at the time of pinhead formation was provided in growing room. Mushroom were picked for 60 days and the weight of mushrooms recorded daily for each tray to determine yield. Yield was determined as kilogram per square meter. The yield response indicated that compost mixture with $22 \%$ soyabean meal as the best yield.

\section{Results And Discussion}

Total nitrogen content of all the composts was same during stacking. For compost $\mathrm{C}-2$ it was maintained by adding $0.7 \mathrm{Kg}$ urea (Table -1$)$.

The yield data of four (C1-C4) compost mixtures (Table -2$)$ showed that composts with soyabean meal were statistically at par with maximum productivity at $22 \%$ soyabean meal. The reduced yield in the compost with $80 \%$ chicken manure is obvious due to uneven nutritional status of the substrate while the low yield in compost with $25 \%$ soyabean meal may be either due to the harboring of parasites and competitors or excess nitrogen in the form of ammonia interfered with spawn run. Yield beyond two months was not recorded; it might be possible that compost with $25 \%$ meal had provided more production beyond that period.

The changes in normal cultivation practices studies in this experiment were found to be significant not only as an alternative to chicken manure but on economic front also. The most significant effect is the emergence of an alternative of chicken manure. Not only soyabean meal (De-oiled cake) which proved its efficiency during the experiments other kind of meals from protein rich seeds like cotton, groundnut, sesame etc. can be considered for straw based compost preparation.

Problems of odor, air pollution as well as anaerobic clumps which were always attached with chicken manure are supposed to be not related with these proteins rich meals. Unlike chicken manure these meals are found to be homogenous and with appropriate characteristics like protein content, fibers, fat and Carbohydrates etc. on economic front these characterized well maintained and packed meals can be obtained form organized markets at a cheaper rate than chicken manure if costs of labor, loading, unloading, cartage etc. are put into consideration.

\section{Tables}

Table 1: Composition of Composts

\begin{tabular}{|c|c|c|c|c|}
\hline Ingredients $\mathrm{Kg}$ & $\mathrm{C}-1$ & $\mathrm{C}-2$ & $\mathrm{C}-3$ & $\mathrm{C}-4$ \\
\hline Wheat Straw & 300 & 300 & 300 & 300 \\
\hline Soyabean Meal & - & 54 & 66 & 75 \\
\hline Chicken manure & 240 & - & - & - \\
\hline Urea & - & .7 & - & - \\
\hline Gypsum & 25 & 25 & 25 & 25 \\
\hline Nuvon (ml) & 30 & 30 & 30 & 30 \\
\hline
\end{tabular}

Table 2: 60 days yield" (Kg) from composts

\begin{tabular}{|c|c|c|c|c|}
\hline Compost & $\begin{array}{l}\text { Yield } / \mathrm{m}^{2} \\
\text { (a) } \\
1 \text { month }\end{array}$ & $\begin{array}{l}\text { Yield } / \mathrm{m}^{2} \\
\text { (b) } \\
2 \text { month }\end{array}$ & $\begin{array}{l}\text { Yield } / \mathrm{m}^{2} \\
(\mathrm{a}+\mathrm{b})\end{array}$ & $\begin{array}{l}\text { Yield/mT of } \\
\text { Compost }\end{array}$ \\
\hline $\mathrm{C}-1$ & 7 & 6.7 & 13.7 & 170 \\
\hline $\mathrm{C}-2$ & 11.1 & 7.4 & 18.5 & 229 \\
\hline C-3 & 11.8 & 9.8 & 21.6 & 265 \\
\hline C-4 & 10.4 & 8.1 & 18.5 & 228 \\
\hline
\end{tabular}

*Mean of four trials.

\section{References}

[1]. Dhar, B.L.B. Vijay, R.C. Upadhyay and H.S. Sohi. 1985. Effect of chicken manure supplementation in compost on yield of Agaricus bisporus. Ind. J. Mycol \& PI Pathol. 15(I), VIII (abstract)

[2]. Hayes, W.A. and T.R. Shandilya. 1977. Casing soil and compost substrates used in artificial culture of Agaricus bisporus, the cultivated mushroom. Ind. J. Mycol \& PI Pathol. 7:5-10.

[3]. Miller, F.C. 1993. In proceedings of the international composting research symposium. (H.A.J. Hoitink and H.M. Keener, eds). Renaissance Publications, Worthington, Ohio. pp 262-281.

[4]. Schisler, L.C. 1964. Nutrient supplementation of compost during mushroom growth cycle. MGA Bull., 179:503-537.

[5]. Shandilya, T.R. 1976. Prepare mushroom compost on wheat straw plus chicken manure. Ind. J. Mushroom. 2(1):43-45

[6]. Shandilya, T.R. 1980. Wheat straw and chicken manure mixture as high yielding substrate for Agaricus bisporus. Taiwan Mushrooms, 4:6-12.

[7]. Shandilya, T.R., W.A. Hayes and P.K. Seth. 1976. Pasteurization of mushroom compost. Ind. J. Mushroom, 2(1):1 -3 